Behavior and Social Issues, 26, 200-203 (2017). (C) Vívica Lé Sénéchal Machado \& João Claudio Todorov. Readers of this article may copy it without the copyright owner's permission, if the author and publisher are acknowledged in the copy and the copy is used for educational, not-for-profit purposes. doi: 10.5210/BSI.V.26I0.7933

\title{
Crossing the Crosswalk: HoW to MAKe A City Walk THe Line
}

\author{
Vívica Lé Sénéchal Machado ${ }^{1}$ \\ Faculdades Integradas Pitágoras de Montes Claro \\ João Claudio Todorov \\ Universidade de Brasília
}

\begin{abstract}
Stopping for pedestrians in the crosswalk is a longstanding legal mandate in Brazil, but is rarely obeyed or enforced, except in the Brazilian capital, Brasilia where yielding is almost universal because of a campaign planned and developed as a joint effort of government, universities, the media and non-governmental organizations. An overview of the process that resulted in large scale change in cultural practices is presented in this brief report.

KEYWORDS: pedestrian safety, traffic safety, Paz no Trânsito, changing cultural practices

In 1996 Brasilia, DF, Brazil was a city characterized by high speeding cars and a significant number of accidents. A campaign was organized involving several key institutions of civil society (media, churches, the University of Brasília) and government (police and the traffic department of Brasília) acting together. The campaign reduced urban speed and established the cultural practice of respecting crosswalks: practically all drivers in Brasília now stop for the pedestrians crossing the street in the crosswalk. This present paper describes in behavior analytic terms the actions of these institutions that established that change in a cultural practice and discuss this change applying the concept of metacontingency as a conceptual tool to understand this cultural phenomenon.
\end{abstract}

\section{Government}

In July of 1995 the Govern of Brasília created the "Safety Traffic Program" with the purpose of reducing the number of traffic accidents. In October of 1996 the Govern modified and enlarged the Program including new actions that were not present before: stimulated the participation of the civil population in the combat against the dangerous driving behaviors and organized publicity campaigns to set up a motivating operation for changing driving behavior. This new Program was called "Paz no Trânsito."

\footnotetext{
${ }^{1}$ The present work is based on a Master's dissertation presented by V.L.S. Machado to the University of Brasilia and in an article published in Portuguese (Lé Sénéchal-Machado \& Todorov, 2008). J. C. Todorov is Bolsista de Produtividade Científica 1D of CNPq (Brazil). Email: joaoclaudio.todorov@ gmail.com
} 


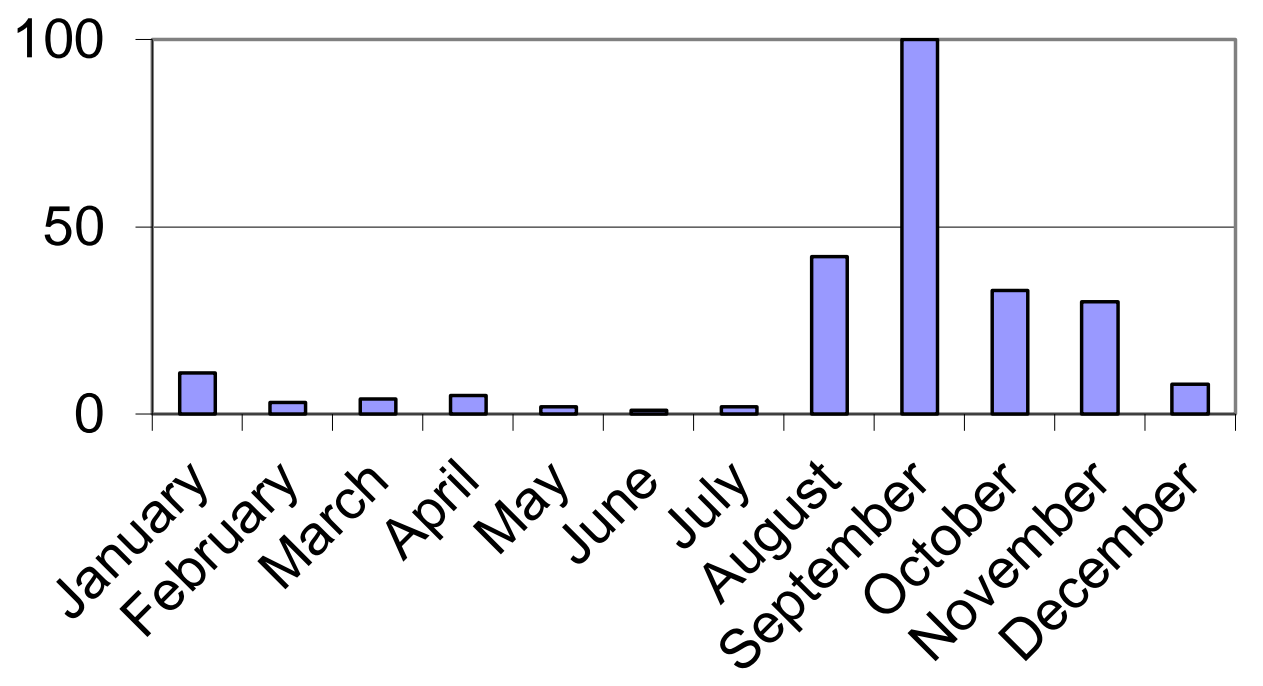

Figure 1. Number of articles on accidents on the streets published in the newspaper "Correio Braziliense" in 1996, before and after it joined the campaign in August of 1996. Data from Lé Sénéchal-Machado \& Todorov (2008).

\section{The Media}

The newspaper "Correio Braziliense" joined the campaign in August of 1996, publishing 241 articles about the traffic of Brasilia, double the number from the previous year. Figure 1 shows the increase in publications related to the topic during 1996. Non-governmental organizations in partnership with the newspaper organized a protest march asking for peace in the streets. The walk brought together about 25 thousand people of different sections of the society (politicians, artists, students, religious leaders) dressed in white. Other newspapers plus radios and television stations participated and contributed to the Campaign drawing attention to the serious level of traffic carnage and stimulating people to engage in the campaign and participate in the protest march.

\section{University of Brasília}

In the end of 1996 the University of Brasilia organized a permanent group for discussion about the traffic problems of Brasília, in partnership with the Government of the Federal District and civil society organizations. In the second meeting of the Group (January 1997) the Captain of the Traffic Battalion of the Military Police of Brasília proposed that the law giving priority to pedestrians in crosswalks should be finally enforced beginning in April of that year. The proposal needed to be voted on and approved by the Group to be enforced.

During the months of January, February, and March of 1997 the Military Police oversaw instructing the population, drivers and pedestrians, about the law and how to obey it. The guards were in the main crosswalks of the city. They stopped the cars before the line so that the pedestrians could cross the street in the crosswalk. They taught the pedestrians to cross the street only in the crosswalk: the pedestrians should approach the crosswalk, stop, look both ways, wait for the vehicles to stop and then cross the street. No fine was applied, only verbal warnings. The police had a theater group that demonstrated correct crossing behavior in the streets showing the safety principles in the traffic including the walking in the crosswalk, with support from the media: videos 
Behavior and Social Issues, 26, 200-203 (2017). (C Vívica Lé Sénéchal Machado \& João Claudio Todorov. Readers of this article may copy it without the copyright owner's permission, if the author and publisher are acknowledged in the copy and the copy is used for educational, not-for-profit purposes. doi: 10.5210/BSI.V.26I0.7933

in television stations, pictures in the newspapers showing examples of the new behaviors required of drivers and pedestrians. The churches celebrated a "Reflection Day" asking for peace in the traffic and emphasizing the respect for pedestrians in the crosswalk.

On April $1^{\text {st }}$ the law began to be enforced. Only about 65 fines were applied in the first week of April. Policemen were hidden from drivers, because the practice to be shaped was that drivers respect pedestrians, not only policemen.

\section{Maintenance of a New Cultural Practice}

Since then, government has been taking engineering measures to help the enforcement and respect of the old law: painting and signaling new crosswalks in appropriate places, removing those that were in dangerous places. In September of 1997 the government organized an educative campaign called "Give a Life Signal" with the purpose to establish walking the crosswalk even more safe; pedestrians should make a signal with the arm (Crowley-Koch, Van Houten, \& Lim, 2011; Van Houten, Malenfant, and Rolider, 1985) before crossing the street so that they would be more visible for the drivers. A theater group made performances in the streets showing how to walk the crosswalk correctly.

\section{Description in Behavior Analytic Terms}

Latinem and Rakos (1997) identified four types of stimulus control usually used by the media: establishing operations (Laraway, Snycerski, Michael, \& Poling, 2003; Michael, 2000), discriminative stimuli and rules (Okouchi, 1999; Rakos, 1993; Schlinger, 1993; Schlinger \& Blakely, 1994) and symbols (de Almeida, \& de Rose, 2015; Sidman, 1997; Silveira, Aggio, Cortez, Bortoloti, Rico \& de Rose, 2016). Newspapers, radio, and television stations worked to teach rules (description of contingencies) to drivers and pedestrians regarding the function of crosswalks, furnished models of desired behaviors. The education of drivers and pedestrians was completed with the work of policemen asking pedestrians to use the crosswalk and stopping drivers who did not respect the law that had been in effect for a long time but never previously enforced.

\section{References}

de Almeida, J.H., \& de Rose, J.C. (2015). Changing the meaningfulness of abstract stimuli by the reorganization of equivalence classes: effects of delayed matching. The Psychological Record, 65, 451-461. doi: $10.1007 / \mathrm{s} 40732-015-0120-9$

Crowley-Koch, B., Van Houten, R., \& Lim, E. (2011). Pedestrians prompt motorists to yield at crosswalks. Journal of Applied Behavior Analysis, 44, 121-126. doi:10.1901/jaba.2011.44-121

Laitinen, R. E., \& Rakos, R. F. (1997). Corporate control of midia and propaganda: A behavior analysis. In P. A. Lamal (Ed.), Cultural contingencies - behavior analytic perspectives on cultural practices (pp. 237-267). Westport, CT: Praeger.

Laraway, S., Snycerski, S., Michael, J., \& Poling, A. (2003). Motivating operations and terms to describe them: Some further refinements. Journal of Applied Behavior Analysis, 36, 407-414. doi:10.1901/jaba.2003.36-407

Lé Sénéchal-Machado, V., \& Todorov, J. C. (2008). A travessia na faixa de pedestre em Brasília (DF/Brasil): exemplo de uma intervenção cultural. [Walking the crosswalk in Brasilia (DF/Brasil): an example of cultural intervention]. Revista Brasileira de Análise do Comportamento/Brazilian Journal of Behavior Analysis, 4, 191204. doi:10.18542/rebac.v4i2.850

Michael, J. (2000). Implications and refinements of the establishing operation concept. Journal of Applied Behavior Analysis, 33, 401-410. doi:10.1901/jaba.2000.33-401

Okouchi, H. (1999). Instructions as discriminative stimuli. Journal of the Experimental Analysis of Behavior, 72 , 205-214. doi:10.1901/jeab.1999.72-205 
Rakos, R. F. (1993). Propaganda as stimulus control: The case of the Iraqi invasion of Kuwait. Behavior and Social Issues, 3, 35-62. doi:10.5210/bsi.v3i1.198

Schlinger Jr, H. D. (1993). Separating discriminative and function-altering effects of verbal stimuli. The Behavior Analyst, 16, 9-23. doi:10.1007/bf03392605

Schlinger Jr, H. D., \& Blakely, E. (1994). A descriptive taxonomy of environmental operations and its implications for behavior analysis. The Behavior Analyst, 17, 43-57. doi:10.1007/bf03392652

Sidman, M. (1997). Equivalence relations. Journal of the Experimental Analysis of Behavior, 68, 258-266. doi:10.1901/jeab.1997.68-258

Silveira, M. V., Aggio, N. M., Cortez, M., D., Bortoloti, R., Rico, V. V., \& de Rose, J. C. (2016). Maintenance of equivalence classes and transfer of functions: the role of the nature of stimuli. The Psychological Record, 66, 65-74. doi:10.1007/s40732-015-0152-1

Van Houten, R., Malenfant, L. \& Rolider, A. (1985). Increasing driver yielding and pedestrian signaling with prompting, feedback, and enforcement. Journal of Applied Behavior Analysis, 18, 103-115. doi: $\underline{10.1901 / \mathrm{jaba} .1985 .18-103}$ 